\title{
Shakespeare'in Teatralliği: Hamlet, Macbeth ve Othello*
}

Elif AYDINALP**

Aydınalp, E. (2019). Shakespeare'in Teatralliği: Hamlet, Macbeth ve Othello. YEDİ: Sanat, Tasarım ve Bilim Dergisi. Kış 2019 (21), s. 1-9.

Araştırma Makale / Research Article

özet

Bu çalışmada tiyatronun temel unsuru olan fakat gündelik yaşamda ve diğer sanat dallarında kendine genişçe yer bulan teatrallik kavramı ana hatlarıyla tartışılmaya çalışılmış, buradan hareketle Shakespeare'in en bilinen tragedyaları Hamlet, Macbeth, ve Othello üzerinden teatral örnekler somutlaştırılmaya çalışılmıştır. Öncelikle teatrallik kavramının temel kuramsal çerçevesi oluşturularak metafor, bakış, ten, rol ve kendilik kavramları ile ilişkisi ortaya konmuş; fenomenolojik bir çerçeve çizilmiştir. Bu bağlamda oyunlarda ironi, parodi, bilmecemsi ve çift anlamlı sözcük kullanımı gibi dilde teatral unsurlarla karşılaşılmış; karakter, oyuncu, oyun ve gerçeklik üzerine düşünülerek, temelde teatralliğin kendini gösterme biçimine odaklanılmıştır. Sonuç olarak "bütün Dünya bir sahne” olabileceği gibi bütün sahnenin de bir Dünya olabileceği fikriyle teatralliğin tiyatro ve gündelik yaşamda yaratıcı ve dönüştürücü gücü vurgulanmıştır.

Anahtar Sözcükler: tiyatro, teatrallik, Shakespeare, metafor, ironi.

\section{Shakespeare's Theatricality: Hamlet, Macbeth and Othello}

\section{Abstract}

This article attempts to discuss the concept of theatricality, the main component of theatre which is commonly used in daily life and other branches of art as well, and to examine the examples of theatricality in Shakespeare's most famous tragedies: Hamlet, Macbeth and Othello. Firstly, the theoretical framework of theatricality and phenomenological attitude are drawn, and the relationship between theatricality and the concepts of "metaphor", "gaze", "flesh and body", "role and self" is introduced. Within this context, the linguistic elements creating theatricality such as irony, parody, riddling, puns are pointed out; playing, reality, character and actor are considered from a theatrical perspective with reference to the issue of theatricality. Consequently, it is emphasized that (presenting the -self within the representation) like "The World [can be] a stage", the stage can be a World and that theatricality has a creative and transformative power in both theatre and daily life.

Keywords: theatre, theatricality, Shakespeare, metaphor, irony. 


\section{Giriş}

Peter Brook 1994 yılında "Shakespeare'i ancak unuttuğumuzda yeniden bulmaya başlayabiliriz” (Brook, 2010, s. 43) demişti. Shakespeare üzerine yazmak, hâli hazırda yazılmış ve onu "bulan" binlerce kaynak arasında kolay bir işmiş gibi görünmekle beraber, tıpkı çeviride olduğu gibi belli bir zorluğu da beraberinde getirmekte, Shakespeare üzerine bilineni tekrarlamak, onun elden kaçan yanlarının görülmesinden alıkoymaz ve ifadenin hep bir biçimde eksik dile getirilmesinin verdiği hazla, kişi onun belli bir unutuş ve hatırlayışla bulunmayı talep ettiğini gözetmek durumunda kalır. Bu çalışmada Shakespeare'in tekrar anılmasının bir sebebi kişisel olarak bu hazzı deneyimlemekse, diğer önemli bir sebebi onun tiyatroya en çok benzeyen yazar olarak teatrallik kavramıla birlikte ilk akla gelen kişi olmasıdır: Hiçbir zaman belli bir kalıba yerleştirilemeyen -bu nedenle birçok kalıba girebilen- sahne ve dünyanın bir metafor gibi işlediği, karakter ve oyuncunun yüzlerinin iç içe geçtiği, gündelik hayatın şiirsel bir biçimde deneyimlenebildiği oyun dünyasına Shakespeare'le birçok farklı kapılardan girilebilmektedir. Bu çalışmada Shakespeare'in oyunlarında sunduğu olanaklardan yola çıkılarak teatrallik kavramı fenomenolojik bir bakış açısıyla okunmaya çalışılmış, tiyatronun kendi araçlarının vurgulanmasına ve kendisine işaret ettiği noktaların bir arada ifade edilmesine çalışılmıştır. Tiyatronun günümüzde daha çok performatif uygulamalara yönelerek beden, mekân, an gibi mefhumlar üzerine yoğunlaşması, tiyatronun araçlarını üretici ve yaratıcı bir gözle yeniden düşünmeyi gerektirmiş, Shakespeare metinleri de bu bağlamda ele alınmaya çalışılmıştır.

\section{Teatreal Oyuk ve Metafor}

Tiyatronun temelde seyircinin ve gündeliğin mekânını paylaşıyor olması, kendisini anın içinde ve bir şeyle (seyirciyle) var ediyor olması, dolayısıyla kendisini bakışa açması minimalist ve yoz sanatın emareleri olarak görülmüştür (Fried, 2003, s. $829,830,832$ ). Sanatların tiyatroya yaklaştıkça yozlaştığı iddiası, onun ne o ne o, hem o hem o olmasından; örneğin oyuncunun hem oyun kişisi hem oyuncu olarak aynı anda sahnede kendini görünür ve var kılmasından ileri gelmektedir. Dolayısıyla pejoratif anlamda işaret edilen bu özellikler tam da tiyatronun temel doğasını açığa çıkarmasıyla bizi ilgilendirmektedir.

Zamanın süremsel olması teatraldir. Tiyatroda ne kadar önceden planlanılmış olsa da en basit hâliyle bir sürece or- tak oluş söz konusudur. Sahnede görünen, duyulan her şey kendini an'ın içinde var etmek durumundadır. Var olan şey, planlananın dışına çıkabildiği gibi kendini bütünlüklü ve bitmiş ya da tam olarak tarif etme imkânını hep kaçırır. Fried, tükenmişliğin eşiğinde olan resim sanatının özelliklerini ortaya koyarken referans aldığı noktada bir anlamda teatralliğin tanımını yapmaktadır. Fried, modern sanatla minimal sanatı karşılaştırırken önemli iki kavram üzerinde durur: "presence" ve "presentness". "Tiyatro, sanatın olumsuzlanmasıdır... Çünkü bir sahne presence’ı açar,” (Fried, 2003, s. 826) der. Modern sanata atfettiği "presentness" ansal, kendinden -yani kendiyle dopdolu, olmak için başkasına ihtiyaç duymayan-, bir tür an'ın kendini genişletmesi olarak düşünülebilir. Olmak için nesnesine ihtiyaç duymaz ve yüce bir noktaya işaret eder. Ancak "presence", varlık gösterme'dir, görülmeye ihtiyaç duyar. İzleyicinin zaman ve mekânını paylaşır, gündelik olanı da içerir, tekillikle değil çoğulluğuyla sonsuzdur (Carlson, 2013, s. 193). Kabaca bir görünüş, kendini sunma ve bir dış kabukla ifade edebileceğimiz oyunsu alan, Fried'a göre modern sanatın sahip olması gereken doluluktan, azamet ve kendine yeterlilikten yoksun ve eksiklidir. Tiyatronun da kendini bir görünüş ve bir kabukla var ettiğini, bunu yaparken kendini bakışa ve sürece açtığını söyleyebiliriz.

Teatrallik, buradan yola çıkılarak ilişkisellikle birlikte okunur; sahne ve seyir yeri arasındaki dönüştürücü bakış bu ilişkisellikte devreye girer. Anne-Britt Gran’a göre izleyici ve sahnedeki performans arasındaki ilişki, gerçek ve kurgusal alan arasındaki ilişki, oyuncunun gündelik dünya ile sahneye düşen seçilmiş, karnavalesk dünya arasında kurduğu ilişki teatralliği oluşturmaktadır (Tronstad, 2002, s. 216, 217). Yani teatrallik, sahne ve seyir yeri arasındaki o oyukta tanımlanmakta; tiyatrosal anlamda üretici bir güç potansiyeli taşımakla birlikte oyuncu veya izleyici için -tam da oyukta yer alınması sebebiyle- gerçek hayatı da dönüştürebilmektedir.

Teatral oyuğun, eşzamanlı olarak hem özdeşleşme hem bir özdeşleşmeme durumu içermesiyle, böylelikle iki farklı yüzeye dokunarak yeni bir anlam taşımasıyla tıpkı bir metafor gibi işlediği söylenebilir. Teatral görüngüleri iç içe geçmiş metaforik bir yapıyla birlikte okuyan ve farklı bir açıdan yorumlayan Ragnhild Tronstad, “Dünya bir Sahne Olabilir mi?” adlı makalesinde teatralliği metaforla ilişkilendirerek bizi Shakespeare'in dünyasına yaklaştırır. Tronstad'a göre teatrallik, sık sık kendini tiyatro ve dünya arasındaki ilişki üzerinden tarif etmiştir (Tronstad, 2002, s. 218). "Theatrum mundi” (bir 
sahne olarak dünya) ve Shakespeare'in "All the World is a stage" (bütün dünya bir sahnedir) metaforu, bir anlamda bu ilişkinin tarifidir. Teatrallikle gerçek hayat ilişkisi, metaforla bir sözcüğün sözlük anlamı arasındaki ilişki gibidir. Bu bağlamda bakıldığında metaforik anlam, meydana getirdiği bir tür “çöküşle" -iki farklı sözcük olan dünya'nın ve sahne'nin kelimesel ve içerik olarak çöküşüyle- iki alana da değebilen bir farkındalık ve belirsizliklerin giderilebildiği bir "vâkıf olma" alanı tanır (Ricoeur, 1978, s. 146). Carlson'ın (2013, s. 79) özetlediği gibi, teatral çerçeve içindeki malzemenin kendine özgü “aradalık” niteliği “belli bir gerçeklik türü” olarak adlandırılır. Böylelikle iki farklı düzlemi birleştirerek farklı bir çerçeveden dünyaya/sahneye bakmamızı sağlayan tiyatro, sadece sahneyi değil dünyayı da teatral kılmakta; böylelikle iki alan arasındaki ayrım silinmektedir.

Teatralliğin özgönderimsel formu, temsilin sınırları karşısında bir antagonist gibi işler: Bir şeyi temsil etmekle mükellef tiyatronun, teatralliği daha fazla açığa çıkardığı ve araçsallığı bir süre iptal ederek kendine gönderme yaptığı durumlarda kendini Dünyaya dönüştürerek temsilin bir tür başarısızlığını işaret ettiği gözlenir. Venedik Taciri'nin başında Antonio bunu şöyle ifade eder: "Benim için dünya neyse odur, Gratiano / Bir sahne yani; herkesin de bir rolü var / Benimkine dertli adam düştü” (2000, s. 35). Bu kez sahne, dünya metaforuyla işlemektedir. Ancak orası bir sahnedir ve sahne olarak "dünya" daima bir şeyin temsili, kendinden başkasının göstereni olmak durumundadır. Burada oyuncu rolüne bağlıdır ve Antonio'nun sıkıntısının sebebi bilinmez, ona çizilen rol budur sadece. Dolayısıyla oyuncunun da "kader"inden bahsedilebilir; Dünya ve oyuncu, göründüklerinin ne fazlası ne de azıysa; kendileriyle eşit veya özdeş de olamazlar. Diğer bir deyişle bütün Dünya bir sahne olabileceği gibi bütün sahne de bir Dünya olarak görülebilir fikri, özdeşlik ve farklılık ihtimalleri üzerinde, öz benlik ve öz varlık üzerinde aşındırıcı bir etkiye sahiptir (Baldo, 1985, s. 116).

\section{Bakış ve Ten, Rol ve Kendilik}

Tiyatro bir anlamda "seyirlik yer" demektir. Bugün Türkçede kullandığımız "manzara” kelimesi ise seyredilen yer anlamında, Osmanlıca'da manzar kelimesinden gelmektedir ve manzar, "nazar” yani "bakış”, "görünüş” gibi anlamları da içerir (Güçbilmez, ders notu, 2011). Kelimenin tarihsel kullanımında seyir yeri, görünüş bir tür görme biçimiyle beraber düşünülür. Görme ve görülme üzerine kurulu tiyatroda ve teatralliğin icrasında; kişinin ancak bir başkası yoluyla kendini bir bütün olarak ortaya koyabildiği, öteki tarafından görülebileceğini bilmenin benliği tanımladığı, öznenin ancak özneler arası bir ilişki biçiminde var olabildiği fenomenolojik kavramlar özellikle önem kazanır. Çünkü bahsedileceği üzere fenomenal bakış, seyredilen ve seyredenin aynı anda gören ve görülen olarak dâhil olduğu metaforik bir anlam üretecektir.

Tiyatronun teatrallikten kaçamamasının bir nedeni, kendini sürekli bakışa açmasından ileri gelir. "Teatral olan, göze çarpan değil kendini bilinçli bir biçimde bakışa açan şeydir ve kendini seyir nesnesi hâline getirmekten kaçınmaz" (Güçbilmez, ders notu, 2011). Bakışım ilkesi, öznenin bir süreç içinde -sonradan- yaratılmasına olanak tanımasıyla günümüz performans çalışmalarını doğrudan etkileyecektir. Ten ve oyuncu, kendini var edebilmek için dünyayı veya sahneyi karşısına alan değil, dünyaya ve sahneye karışmış bir bedenin kabuğu gibidirler. Böylelikle kişi kendi varlığını bir ten gibi inşa ederken oyuncu da bu sürecin bir parçası olarak kendini gören ve kendi üstüne düşünen teatral bir özellik kazanır. Dünya ve sahne bize karşıdan görünür. Ancak dünyanın ve sahnenin içinde de olduğumuz su götürmez bir gerçektir. Ponty'nin $(2006$, s. 33,47) tarif ettiği “ten”, metaforun ve aynı zamanda teatralliğin oyuğunu işaret eder; nesnenin, ona benzememek koşuluyla kurduğu imgenin gücünü açığa çıkarır. Teatrallik, temsil ettiği varsayılan benzediği şey ile arasına mesafe koyarak bunu gösterir.

Buradan hareketle benlik ve rol kavramları üzerine tekrar düşünmek gerekir. Özdeşleşme ve rollerin saflığını doğası itibariyle reddeden tiyatronun bu özelliğinden yola çıkılarak gündelik hayata atfedilen kendiliğin bir yanılsamadan ibaret olduğu, kendisini sahne üzerinde var eden oyuncunun kendini dünya içinde var eden kişiden çok farklı olmadığını iddia eder Erving Goffman (Goffman, 2014, s. 236, 237). Kendiliğin, tıpkı bir oyuncu gibi kişinin tüm eylemlerinin -yani günlük hayatta sergilediği performanslarının- toplamından ve etkileşim hâlindeki seyirci tarafından yorumlanmasıyla ortaya çıkan bir ürün, bir süreç olduğu belirtilmektedir (Goffman, 2014, s. 234). "İnsanın bir içi yoktur, insan dünyanın içindedir ve ancak dünyanın içinde kendini bilebilir” (Ponty, 2010, s. xi). Diderot'nun tarif ettiği oyuncu da sürekli kendisini duyabilir, kendisini görebilir, kendisini tartabilir ve uyandıracağı izlenimleri kollayarak sahne üstünde duygusunu tekrar edilebilir ve her istendiğinde ortaya çıkarılabilir kılmak durumundadır (Karaboğa, 2011, s. 21). 
Kendini ancak bu biçimde var edebilen oyuncu, gündelik yaşamda da kendini tekrarlarla inşa eden kendilik mefhumundan uzak değildir. Bir temsil icracısı olan oyuncu için kendilik veya benlik gibi kavramlar, gündelik yaşamdaki gibi eylem ve ilişkisellik içinde kendine farklı adlar bulur; kişi veya oyuncu, kendini bütünlüklü ve değişmez olarak sunan an'ın toplamından ziyade tiyatroya çok benzer bir biçimde heterojen süreçleri içermektedir. Bu bağlamda Macbeth, kendi hikâyesini yaşarken ve yazarın insana dair kurduğu çerçeveyi genişletirken, herhangi bir oyuncunun bu doğasını da açı etmektedir. Bu nedenle Shakespeare'in karakterleri kurgu uzamında kendilerini var ederken sürekli oyun ve oyuncuya atıfta bulunmakta; oyuncunun sahne üzerinde kendini var etme süreci, Hamlet'in kendini var etme sürecine yapışık gibi görünmektedir. Böylelikle sahnenin dünyayla kurduğu metaforik ilişki gibi, Shakespeare karakterleri rol ve kendilik üzerinden oyuncuyla paradoksal bir bağ kurarak teatral oyuğun oluşmasına olanak tanımaktadır.

\section{İroninin gücü: Dilsel Teatrallik ve Teatral Söylem}

Tüm bu açılardan bakıldığında Shakespeare oyunlarında dramatik kırılmaların yaşandığı ve sahnede ironi, parodi, alaya alma, gülünç öğeler, komediye özgü olan bedensel komiklikler ve zıtlıkların kurulma yöntemiyle teatralliğin hatırlatıldığı yerlerde belli bir mesafe ortaya çıkar. Bu mesafe sayesindedir ki seyirci ve oyuncunun bakışı teatral ve dönüştürücü bir güce sahip olur. Diğer yandan, paradoksal bir biçimde, mesafe sayesinde rol ve kendilik, oyuncu ve seyirci, gündelik yaşam ve kurgu arasındaki geçişler artar; kimlikler Macbeth'in gördüğü gibi yüzen, içi boş gösterenlere dönüşür. Hamlet’te dönemin intikam konusu ve tragedya formu oyunun yapısı itibariyle parodize edilir. Parodinin ve ironinin işlemesi, oyun içinde absürd diyebileceğimiz komikliklerin yer alması; ağırbaşlı bir tür olan tragedyada ve beklentide bulunulan trajik kahramanda genel olarak bir yarılmaya yol açar, teatral mesafe devreye girer, oyunsuluk kendini sık sık hatırlatır.

Hamlet saray içinde deli taklidi yaparken kimseye açık vermeyen ancak apar ve monologlarla "içini” defalarca seyirciye açan bir roller geçidi sunmaktadır: "Kalbimi kahpeler gibi lafla ortaya seriyorum!” (2005, s. 109). Kendi içini sürekli açan Hamlet, ironik bir biçimde sahnede içine dair kimseye en ufak bir açık vermez, onu teatral bir örtüyle kapatır, oyunsu yanıyla kafa karıştırır. Oyuncunun hünerini ve yapaylığını en çok gösterdiği bu sahnelerde Hamlet, en sahici anlarını seyir- ciyle görülme üzerinden kurar. Diğer yandan, alaya alma ve çift anlamlı sözcüklerle kurduğu ironik dil; tiyatronun materyallerinin sürekli hatırlanmasında, dramatik bağın ve özdeşliğin kopmasında önemlidir.

Oyunculukla yoğrulan Hamlet'in sürekli ve kusursuz kimlikler geçişi her daim "karşıdan” görülen bir dünyanın tahayyül edilmesini şart koşar. Karakterin kendini gerçekleştirebilmesi için talep ettiği uzaklık, tiyatronun kendini gerçekleştirmesinde yazarın kurduğu uzaklığa benzer. Beliz Güçbilmez İroni ve Dram Sanatı'nda Shakespeare'in oyun yazarı olarak tiyatronun kendini gerçekleştirebilmesi için bir tür "estetik uzaklık” yaratması gerektiği gerçeğinin farkında olmasının, onun yazma biçimini büyük ölçüde etkilediğinden, ona ironist sıfatını kazandırdığından bahseder:

Shakespeare, söz konusu estetik uzaklığı, oyun içinde oyun, oyun içinde yönetmen, oyun içinde yazar, oyun içinde oyuncu gibi tiyatroya özgü araçları son derece başarıyla harmanlayarak yaratır... Bir oyunu, içine başka bir oyun yerleştirerek “ters yüz etme"nin, “içini dışına çıkarma”nın yarattığı ironik etki, yanılsama/gerçeklik ilişkisini yeniden kurar. İzleyici açısından içerideki oyun, "bir oyun” olma özelliğiyle algılanır algılanmaz onu çevreleyen asıl oyun, yanılsama olan'dan gerçek olan'a dönüşür. Ancak bu durum, izleyiciyi, içerideki oyunla ilişkisinde bir "estetik uzaklık”a itince, izleyici açısından aynı mekanizma, dışarıdaki, yanılsamadan gerçeğe, oyundan yaşama dönüşmüş oyun için de çalıştırır kendisini. Oyun içinde oyun bittiğinde, izleyici itildiği mesafeyi koruyarak; bu bilinci saklı tutarak, izleyecektir ana oyunu da (Güçbilmez, 2005, s. 66, 67).

Oyun içinde hem yaşayan ve temsil eden olarak hem de tanıklık eden olarak karakterin ve oyuncunun varlık inşasında bulunulduğu görülmektedir. Hamlet, kendini sürekli denetleyen, yorumlayan bir göz olarak kendi gülünçlüğüne ve acısına dışarıdan bakabilmekte; diğer yandan sarayın ve seyircinin gözlerinin üzerinde olduğunu bilerek hareket etmektedir. Oyunun tamamına yansıyan ironik tutum, şeyleri ters yüz ederek oyunun temel ironisine tekabül etmekte, temsil edilen içerik boşa çıkartılarak Hamlet’in gerçekliği ve kendi varlığ temelde "oynayan" bir oyuncunun kabuğuna dönüşmektedir.

Bu kabuğun oluşmasında, oyun bütünlüğüne ve yanılsamaya hizmet eden dramatik söylem yerine bağlamla kendisi arasına mesafe koyan, kendine yeterlilik iddiası taşıyan veya yersiz -non sequitur- sözcüklerle odak değiştiren teatral söy- 
lemlere fazlaca yer verilir. Teatral proje, özünde konuşmacı ve onun söylemi arasındaki ilişkinin bozulmasının farkındalığı üzerine kuruludur. Bu bozulmadan dolayı, dramanın şartlarının, dilin kurallarının ve misyonunun tam anlamıla işlemesine izin verilmez. Her zaman içinde bulunduğu söylemle bir biçimde ayrı olduğunun farkında olan teatral konuşmacı ya kendini tamamen söyleminden uzaklaştırmaya, ayrıştırmaya (her ikisi de başkalarının dili üzerinden, öznenin ifade ettiği hayalî unsurlarla kendisi arasına mesafe koymasıyla işler; -mış gibi yapılarak oyuncuyla söylemle arasındaki mesafe, esasen oyuncunun yerini sağlamlaştırır) ya da bu ayrılığı abartılı veya savurgan/fazlaca konuşmalarla azaltmaya çalışır. Dolayısıyla abartılı, yapmacık gibi pejoratif anlamlara sahip teatral sözcüğü, alışılmadık biçimde ne yaptığını bilmeyi ve kendi üstüne düşünebilmeyi çağırmaktadır (Baldo, 1985, s.113). "Teatral konuşmacı, söyleminin alıntısallığına dikkat çekmek isterken dramatik söylem -ki gerçekte o da alıntısaldır- bu alıntısallığını ve tırnak içlerini temelde maskelemeye çalışır” (Baldo, 1985, s. 114).

Hamlet'te iç oyunda Oyuncu Hecuba'nın acısını paylaşır gibi görünmeye çalışmakta; dış oyunda ise Claudius kardeşinin ölümünden sonra acılı bir kardeş rolü oynamaya çalışmaktadır. Bu iki "rol” ve söylem arasında farklılıklar bulunur, kendi bağlamları içinde farklı çalışırlar. İç oyundaki Oyuncu konvansiyonel bir biçimde kendisini Hecuba'nın acısına tamamen kaptırması -rolünü yaşamasıyla- oldukça teatraldir. Seyirci, oyun içinde ve aynı anda bu yapaylığa tanık olarak, aslında kendisi de bir oyuncu olan ancak oyun içinde -iç oyuna nazaran- bir derece gerçeklik taşıması gereken Claudius'un acılı kardeş rolüne de mesafeli bakar; güç ve çıkarı uğruna kardeşini öldüren gerçek Claudius'a ancak böyle bir mesafeyle yaklaşılabilmektedir. Dolayısıyla teatral söylemdeki güç, iki alanın görülmesiyle işleyen farkındalık ve gerçekliğin dönüştürülebilme özelliğiyle burada devreye girer; seyirci için rol ve gerçeklik birbirinin içine sızar. Böylelikle iç oyunda yer alan Oyuncu, Hamlet oyununun "gerçekliğini” ve geçerliliğini sarsan teatral bir unsur konumundayken; Claudius oyunun bütününe ve intikam temasının ilerlemesine hizmet eden dramatik bir unsur konumundadır.

Bu bağlamda Hamlet'in ikinci monoloğu önemlidir, burada tamamıla oyuncu ve oyun üzerine gerçekleşen bir iç konuşma yer almaktadır:

Hamlet: Akıl almaz şey değil mi şu oyuncunun yaptığı
Yalnızca bir masalda, bir tutkular rüyasında

Hayal gücüyle zihnine ve bedenine böyle hâkim olması

Yüzünün rengini soldurup, gözlerini yaşartması

Sesini kısarak, kaptırıp gitmesi kendini

Hayalin buyruğuna bedenin tüm ifade gücüyle uyması

Ne müthiş! Ve hepsi bir hiç için

Hekuba için!

Hekuba'dan ona ne, ya da ondan Hekuba'ya (2005, s. 108).

Hamlet, bu sözlerle oyuncunun gerçeğini açık bir dille ortaya koymuş, rolüne bitişik oyun kişisinin imkânsızlığıyla tabiri caizse alay etmiştir. Bir üçüncü çerçevede Hamlet'i oynayan oyuncu için de aynı durum söz konusudur fakat bunu yine onun ağzından duyarız. Bu ayrımın görülmesini, seyircinin Hamlet'i izlerken onu canlandıran oyuncuyu da görmesini sağlayan şey, dış oyunun içinde birçok iç içe geçmiş oyunlar ve oyunsu alanlar keşfetmesidir. "Benim gibilerinin yerle gök arasında sürünüp durmalarının ne anlamı var?” (2005, s. 116) sorusu, aidiyetsizlik hissini ortaya koyduğu gibi, nesirle şiir arasında kalmış oyuncunun sahnesini de belirsiz kılmaktadır.

Hayaletin görünüp kaybolduğu sahnede ise Hamlet, seyirci gibi ağır bir gerçeği öğrenmiş ve kahramansı bir tavırla öcünü almaya yemin etmiştir. Ne var ki akabinde düşüncelerini hemen bir kâğıda yazma gereksinim duyar. Böylesi bir sahneden sonra oğul olmanın getirdiği duygusal özdeşlikten çıkarak sanki ilginç bir olayı dışarıdan gözlemlemiş gibi, kuşkucu bir kimlikle cebinden kâğıt çıkarıp not alması sahnenin gerçekliğini hem seyirciye hem oyuncuya uzaklaştırır. Kılıç üzerine yemin etme sahnesinde ise tamamen farklı bir ruh haline bürünür, arkadaşlarına espri yapar. Özellikle üç kişinin hayalete göre sürekli dönerek elleri kılıcın üstünde yemin etmeye çalışmaları ve bu devinimin uzaması komik bir sahneye neden olur.

Katilin Claudius olduğunun anlaşılmasından sonra da Hamlet'in esprilerinin devam etmesi, Horatio'nun Hamlet'e dönerek “Kafiyeyi tuttursaydınız bari” (2005, s. 132) cevabı, odağı yine dilsel olana çekerek dağıtmaya yardımcı olur: Babasının katilini öğrenen Hamlet’ten ziyade, babasının katilini öğrenmiş bir oğulu oynuyormuş gibi yapan oyuncuya söylenen bir sözdür bu daha çok. Ne var ki Hamlet'e söylenmiştir. Hamlet'in dili, kimi zaman, karakte- 
rin iç'ini doldurmaktan çok onu oynayan oyuncunun kurmaya çalıştığı dile hizmet eder gibidir. Sonunda ise Hamlet karakteri kurulmaya çalışan bu dilin ve görünüşün ötesinde pek bir şey iddia etmeyecek, karakterin içinin, oyun alanının kabuğuna ayrılmaz bir biçimde yapıştığı görülecektir. "Kafiyeyi tutturmak" zorunda olan bir dönem oyuncusu olduğunu unutturmazken, oyuncunun oynadığı Hamlet’in de oyun gerçekliğinde daha fazlası olduğunu işaret etmeye çalışmaz. Veyahut saraya gelen oyunculara bir oyun yönetmeni edasıyla "Hareketi söze, sözü harekete uydurun” (2005, s. 120) direktifinde bulunurken yine karakter Hamlet'in oyun gerçekliğinde yapmaya çaııştığından fazlasını söylemez.

Dolayısıyla Hamlet'in bir iç'i yoktur ve Ponty'den benzer bir biçimde alıntılandığı üzere, dünyanın olduğu kadar sahnenin de içinde olduğumuz gerçeğinden yola çıkılarak Hamlet, kendisini oyun içinde var etmek durumundadır. Onun kararsızlığı ve monologlarındaki “iç dökmeleri” bir öz üzerinden okunabilirken aynı anda ve aynı yolla kavranan teatral oluş hep kendini hatırlatır. Kararsızlık, daha fazla teatral edimlere yol açarken, örneğin intihar üzerine konuşmaları teatral bir jest olarak kalır. Ne var ki seyirci aynı anda onun kararsızlığı$\mathrm{n}$ içerden hissedebilir ve "intihar" konusunda esaslı bir tanıma çarpar. "Hiçbir şeyin gösterisi” olarak, şeylerin nasıl şey olduklarını, dünyanın ve sahnenin nasıl olduğunu göstermek için "şeylerin derisini” delmesi onun karakterin söze, bedene, oyuncuya ve oyuna karıştığı çoklu bir varlık alanı açmasıyla gerçekleşir. Seyirci de bu nedenden ötürü oyunu izlerken sadece kurgusal veya gerçek alana kendini tam anlamıyla yerleştiremeyecek; birine dâhil olabilecek gibi olduğu her anda oyuncu ve oyun yönetmeni Hamlet'in kullandığı dil ve kurduğu teatral mesafe ile rahatsız edilerek bakışını sürekli değiştirmek durumunda kalacaktır.

Teatralliğin aynı oyun içerisinde Ophelia karakteri üzerinden de kurulabileceği görülmektedir. Ophelia'nın iki boyutlu görünüşü bir tür yoğunluk içermekten ziyade kendini işaret eden, seyirciyi birden fazla noktaya odaklanmaya çağıracak dağınıklıktadır ve söylemden ziyade tamamen bedensel bir deneyime tanık olmayı çağırır. Aile bağlılığı ve Hamlet'e olan ilgisinin bilinç düzeyinde kaybolduğu bir noktada Ophelia'nın varlığı kucağında taşıyamadığı kurumuş otlarla birlikte dağıtılmış bir görünüşte sığdırılır; "tanınmış" olmaktan ziyade tüm "Ophelia’lara” ve Ophelia gösterimlerine dair yapaylığın inşa ettiği bir tür yakınlıkta "aşinalık" duygusu talep eder (Bloom, 2013, s. 171). Ophelia'nın şarkı söylediği sahnede de büründüğü görünüşünün tek bir ifadeyle tanımlanmaya ve tüketilmeye direndiğini, tavırlarının geçmişte ve gelecekte yankılanabildiğini görürüz. Kraliçe, Ophelia’ya “Ne demek bu şarkı?” (2005, s. 165) diye sorması bu nedenle boşunadır. Kraliçe Ophelia'yı dinlemiştir ancak esasen -seyircinin de- dinlediği şey Ophelia'dan ziyade bir çeşit gürültünün kendisidir; kendi sesinin yabancılaştığı, anonim baladların, halk türkülerin içinden geçtiği, gittikçe daha fazla sese bürünen bu yüzden de şarkıcı, karakter ve seyirci ilişkisini belirsizleştiren çok katmanlı bir şarkıdır. Şarkının taşıdığı "şey” tıpkı yukarıda bahsedilen alıntılama yöntemi gibi ithaldir; tek bir anlamda toplanılamayacak biçimde başka yerlerden sürüklenip ehlileştirilmemiş biçimde sahnede durmaktadır. Yine karşılaştırmak gerekirse, Hayalet'in ne dediğine odaklanırken Ophelia'nın ne yaptığına odaklanırız. Hayalet'in sesi, dilsel anlama ve dramatik içeriğe hizmet ederken Ophelia'nın kırık sesi yaratıcı bir teatral oluşuma dönüşmektedir (Bloom, 2013, s. 171).

Sonuç olarak Hamlet oyunu, temelde “oynamak” üzerine kurulu meselesi, iç içe geçmiş oyun alanlarının aynı anda görülebildiği yapısı itibariyle geniş bir teatral çerçeve sunmaktadır. Oyunun hikâyesi ve olayların ilerleyişi yine bir oyun gerçekliği üzerinden ilerlerken, karakterlerin kendilerini gerçekleştirdikleri ve seyirciye sundukları kritik anlar, "oynamak" ve "rol” kavramının teatrallikle birlikte düşünülmesini yardımcı olur. Bu anlamda, özellikle Hamlet'in iç oyundaki Oyuncular'la paralellik gösterdiği sahneler, Hamlet'in monolog ve aparlarla kendini seyirciye açtığı sahnelerle üst üste katlanarak oyunun teatral derinliğini artırmaktadır. Benzer bir biçimde, oyun karakterlerinin birbirlerine sürekli "oynadıkları" mekânlar -sarayın odaları ve avlusu- bir yandan gündelik hayatın gerçek mekânlarını illüzyon olarak işlerken, diğer yandan oyunun iç oyunu barındıran yapısı ve diyaloglardaki teatral göndermelerle kaçınılmaz olarak "sahne” gerçekliğine çarparak teatralliğin metafor olarak okunabilmesini sağlamaktadır.

\section{Macbeth'in Cadıları ve Gerçekdışı Alan}

Macbeth oyununda ise teatral gücü temsil eden Cadılar, iki yolla bunu oyuna dâhil ederler: Zaman, mekân ve toplumsal olandan sıyrılmış akışkan varlıkları ve kurdukları bilmecemsi dille Macbeth'i tekinsiz bir kuyuya çağırmaktadırlar. Diğer yandan, Cadılar’ın gerçeklikten uzak bir görüntü çizmeleri, tıpkı doğa gibi aşkın ve gizemli özelliklere sahip olmaları, 
oyun içinde bilinçdışının yıkıcı unsuru olarak işlemelerine sebep olmaktadır.

Doğa gibi herhangi bir etik ve sosyal bağın dışında kendi iç yasasıyla var olan Cadılar, Kant'ın yüce kavramına tekabül ederek özneyi ve onun algısını aşan bir görüntü çizer; yapıtın sınırlarında süzülen, kendine has bir hakikat türüne sahip olan anlam dışının ve şiirsel oyunun âlemine işaret ederler. Kant, gerçekliğin/yücenin hazzına algılanabilir ve tanımlanabilir bütünden ziyade insanın içine dolan ve içiyle sınırlarını yıkan yoğun bir deneyimlemeyle ortak olunabileceğini ima eder. Yüce ilk başta, özneyi özne yapan etkinliği alt üst etmesiyle yıkıcı bir niteliğe sahip olmasıyla birlikte; diyalektik bir biçimde insanın kamusal ve modern yaşama dair kurduklarının, kontrol edici ego'sunun dışında kalarak esasında bireyin unuttuğu yaşamsal kodları hatırlatır (Adorno, 2005, s. 74; Sayın, 2000, s. 39-41). Doğanın bu parçalı, ansal, dolayımSız ve yıkıcı görünümü; diğer yandan tiyatrodaki üretici güç teatrallikle de birlikte okunmaya oldukça uygundur. Doğa'nın ve gerçekdışılığın içerik olarak Macbeth'in üzerindeki dönüştürücü etkisi üzerinde durulabileceği gibi; oyunun sahneye konmasında gerçekdışılıktan birçok açıdan da teatral anlamda faydalanılabileceği açıktır.

Denilebilir ki, oyun içindeki teatral alan, oyunun gerçekliğini belirleyebilme potansiyeli taşır. Benzer bir durum Hamlet'teki oyun içinde oyunun ve Hamlet'in oyunsuluğunun gerçek katili ortaya çıkarmasında, Hamlet'in kaderini tayin etmesinde de ya da bütün oyunun içinde belki de en geniş teatral alana sahip olmasında görülebilir. Cadıların kehanetleriyle başlayan gerçekdışılık, sahnede gerçeklik olarak geri dönmeye devam eder. Macbeth'e söyledikleri sözler onun içindeki ötekilik ve arzu bölgesini harekete geçirerek sağlama alınmış kimliğini paramparça eder. Onu bir kere çağıran bu sesi dönüştürerek kendi sesi yapan Macbeth'in dönüşümü yine teatral geçişlerle seyirciye sunulur.

Dramatik anlamda anlamsız, bağlantısız gibi duran araçlar "dünya ile aralarına koydukları etkin mesafe"den ötürü dönüştürücü ve etkileyici teatral bir güç kazanır. Bu bağlamda, Cadıların akışkan varlıkları ve akışkan dilleri bu gücün kullanılabileceği uygun zemini yaratmaktadır: Oyunun başında üçü birden şöyle der: “Ha iyi, ha kötü; ha kötü, ha iyi.” (2005, s. 20) (Fair is foul, and foul is fair) Cümledeki ilk foul sıfat görevinde ve wicked-kötü anlamında, ikinci foul isim görevinde ve yasalara karşı eylem anlamındadır. Cadıların konuşmalarının çoğu bu tarz ikilem ve kelime oyunlarıyla doludur. Daha sonra ise Macbeth şöyle der: "Hayatımda bu kadar güzel ve kötü bir gün görmedim.” (2005, s. 26) (So foul and fair a day I have n ot seen) Savaşta zaferden dönen Macbeth'in ilk sözünün biraz karanlık ve ikilemli olması, bu açıdan cadıların dilini anımsatması ilginçtir. Kurulan bu cümleler, kullanılan sıfatlar oyunun bütünü düşünüldüğünde aslında hiçbir şey ifade etmemekte, dramatik örgüye hizmet etmemekte ancak seyirciyi belli bir durumun içine çekmeye direnerek ve dikkatleri dilsel malzemeye çekerek belli bir mesafe öngörmektedir.

Maddi dünyadan koparılmış göstergeler olarak kısıtlayıcılıktan uzaklaşmış ve anlamsızlaşmış varlıklarıyla dünya ile aralarına etkin bir mesafe koyan Cadılar, bu hiçlik, zeminsizlik ve tözsüzlükle bir oyun alanı gibi hareket ederler. Kendi içinde bir amaç haline gelmiş ve belirli bir bağlamdan uzak, görünüşle var olan bu göstergeler, Eagleton'ın da belirttiği gibi ironik biçimde, maddi olarak en güçlü olan göstergelerdir (Eagleton, 1998, s. 10). Ve tam da bu nedenle tiyatronun, oyunsu alanın kalbini tarif etmekte, şeyleri dilediğince eğip bükebilmektedirler. Dolayısıyla krallık gibi peşinden koşulan kimlik arayışı ve bununla birlikte içeriğe dair anlam ezgisi çöker veya oyunun sonunda tamamen anlamsızlaşır: Tıpkı Ophelia'nın şarkısının dış oyunun ezgisine uymayıp teatral bir balad olarak konumlanması gibi, geriye yalnızca oyunsu malzeme kalmaktadır. Sonuç olarak temsil edilen tüm gerçeklik ve içerik, kaçık bir Tanrı'nın veya yazarın anlattığı hikâyede birleşir. Macbeth'in oyunun sonunda attığı tiratta bilgece tarif ettiği şey, bir tür bilginin yokluğu hâlidir: İnsan, son tahlilde bir oyuncu gibi bir süre rolünü oynayacak, bildiklerinden çok akıllarda sahnede kurarak var ettiği bir imge olarak görünüşü kalacaktır.

\section{Othello'nun Gerçekliği}

Kıskançlığın ve aşkın hikâyesini anlatan Othello, esasında oyun içindeki kötü karakterin yazıp yönettiği başka bir oyunsu alan barındırır. Bu alan öylesine güçlüdür ki, diğer karakterler -başta Othello- oyun boyunca Iago'nun seyircisi konumundadırlar. Onun izin verdiği kadarını bilen ve duyan Othello, Diderot'un bahsettiği soğukkanlı oyunculuktan oldukça uzaktır. Iago ise tıpkı Hamlet gibi oyunu istediği ölçüde manipüle edebilmekte, seyirciyle monolog aracılığıyla kurduğu teatral bağda ifade ettiği birçok “yalan”ı gerçek kılabilmektedir. Iago, intikam eylemine doğaçlama hazırlanan bir oyuncu gibi sürekli duruma göre tavır alır. 
Örneğin eşini Cassio ile aldattığından güçlü bir biçimde kuşkulanmaya başladığında Cassio ve Iago'nun konuşmalarına kulak misafir olur. Cassio, sevgilisi Bianca'dan bahsetmektedir ve Shakespeare'in seyircisi onun kimden bahsettiğini bilmektedir; ancak konuşmaya kulak misafiri olan Othello, oyun boyunca olduğu gibi Iago'nun seyircisidir ve konuşmayı onun oluşturduğu işaretler üzerinden okumaktadır. Iago, müthiş ikna ve retoriği kullanma yeteneğiyle açtığı teatral yarıktan dilediğini gerçeklik olarak geçirebilmiş, sonrasında ise herhangi bir kanıta gerek duymadan rahatça Desdemona'nın ve Casio'nun öldürülmesi gerekliliğinden bahsedebilmiştir (Beier, 2014, s. 44).

Cadılar'ın doğayı temsil etmesinde ortaya koydukları teatrallik gibi, Iago da Kötü'nün teatral bir sunumunu gerçekleştirir. Ve aynı biçimde Kötü, salt kendini gösterir biçimde sahnedir. Bu açıdan denilebilir ki Iago, oyunun teatral yüzeyini oluşturur, tüm gerçekliği kaplayacak denli içi boş bir görüntüden ibarettir. Benlik, kendilik gibi kavramları temsil etmekten ziyade, tam tersi bir biçimde görüntülerden oluşan alternatif bir gerçeklik yaratır. Shakespeare, Othello oyunuyla Cadılar’a ve Hamlet'e verdiği teatral dönüștürücü gücü bu kez Iago'ya vererek bir yandan dış gerçekliği sorunlu hâle getirmiş diğer yandan oyun'un kendi gerçekliğini ortaya koyabilmeyi başarabilmiştir. Iago, saf bir gerçeklik ve kendilik dışında konumlanan, aldatan ve dönüştüren üretici güçtür. "Görünüşleri gerçeklik zannetmek ile görünüşlerin gerçekliğini tanımak nasıl birbirinden ayrıştırılabilir?” diye sorduğumuzda Iago ve Othello'daki yarığı net bir şekilde görebiliriz. Görünüşleri gerçeklik zannetmek Othello'nun tek yönlü ve masum dünyasına işaret ederken; kendini bu görünüşe yapıştıran tüm yanılsamacı eylem biçimlerini de işaret ediyordur. Diğer yandan, görünüşlerin gerçekliğini tanımak, özdeşlik ilkesini reddeden teatral bir tutumdur; "görünüş" ve "gerçeklik" bilgisini aynı anda işleme koyabilmeyi, bunun için de o şeyden uzaklaşabilmeyi gerektirir. "Çünkü göründüğüm gibi değilim ben” (2007, s. 27) der Iago. Tıpkı Rosencrantz ile Guildernstern'in Hamlet'in gizemini çözmek için geldiklerinde ortada yüreği sökülecek bir gizemin olmaması gibi, Iago da Othello'ya ve etrafındakilere teatral bir kabuk$\tan$ fazlasını göstermez. Oyunun sonuna gelindiğinde ise 0thello, Iago'nun kurduğu görünüş ve retoriğin içinde kendilik düşüncesini tamamen ve acı bir bedelle yitirir: "Artık işi bitti Othello'nun" (2007, s. 119); "Bir zamanlar Othello denirdi ona, buradayım.” (2007, s. 212).
Othello, baştan sona bütün hayatını "olduğu gibi anlatan” (2007, s. 46) olduğu gibi görünen bir adamdır. Bu nedenle Desdemona: "Othello'nun yüzünü ruhunda gördüm” (2007, s. 50) der ve ona âşık olmasını açıklar (I saw Othello's visage in his mind). Yani onun görünüşünü içinde gördüm demek istemiştir. Othello, Iago'dan farklı olarak iç'i olan, her şeyi olduğu gibi anlatan bir karakterdir. Ne var ki kalbini "Kahpeler gibi lafla ortaya seren” Hamlet’ten durumu farklıdır. Othello, Hamlet'in çelişkisini derinleştiren teatral alandan yoksundur. Benjamin V. Beier'e göre de Shakespeare, genel anlamda Othello oyununda ve oyunun içine yerleştirdiği sofistike kötü karakteri ile ikna yolunda etik olmayan eylemlerin etik olanlardan daha güçlü ve inandırıcı olduğunu göstermiştir: Othello, "yaptıkları bir türlü söylediklerini tutmayan" (2007, s. 170) Iago karakteri ile insan bilgisi denilen şeyin ve elbette gerçeklik bilgisinin yanıltıcı ve kara yanını gösterirken yetkin bir retoriğin ve esaslı bir görünüşün gücünü öne çıarmıştır (Beier, 2014, s. 45).

\section{Sonuç}

Theodoros Angelopoulos'un yönettiği Zamanın Tozu filminde iki yaşlı insanın bir evde sahneleri görülmektedir. Yıllar önce yaşan(ma)mış bir olayın provasının alındığı bu sahnede kadın, adamı kapıda defalarca karşılayarak geçmişte söylenmemiş o sözleri sarf eder. Sinemada görülen teatral bir provadır; ancak seyirci geçmişin telafi edilemezliğine dış dünyaya gönderimden uzak bir provayla yaklaşırken işaretler temsil ettiği şeyle arasına mesafe koyarak gerçekliğe tekabül etmekte, böylece gerçekle kurulan bağda gündeliğin ve materyalin estetik dili değer kazanmaktadır.. Hamlet, Macbeth ve Othello'nun oyun içinde yalnızca karakter olarak değil aynı anda oyuncunun bedeni ve dili üzerinden oyunun dramatik bağına direkt hizmet etmeyecek biçimde konumlanışları; bu bağlamda özellikle parodi, ironi ve çift anlamlı sözcüklerden, bedensel komikliklerden ve abartıdan yararlanılması; diğer yandan özellikle Hamlet oyununda net bir biçimde görülen, ama bir yöntem olarak diğer oyunlarda da karşımıza çıkan iç içe geçmiş oyun alanlarıyla sahnenin dünya olarak bir metafor gibi derinlikli işleyiş biçimi klasik bir metni "bir şeyin temsili" olarak okumaktan ziyade kendini çokluğuyla işaret eden teatral bir metin olarak okunmasını sağlamaktadır. İç içe geçmiş iki evrenin kabulüyle, yaşamsal olanın içinde kurgusal aralıkların veya kurguya ait olanda yaşamsal aralıkların fark edilmesini sağlayan teatral konumlanış, tiyatro sanatının kendini işaret etmesinde ve yeniliğinde; benzer bir biçimde yaşama değme- 
de oldukça önem arz etmektedir. Bu nedenle Shakespeare’in ele aldığı tüm oyunsu malzemeyle söylemek istediği şeyleri söylerken temelde bir tür roller ve provalar geçidi sunması; "asıl iş oyunda bitiyor" diyerek oyunun gerçekliğini dile getirişi, gündelik yaşam ve sahnede her zaman yeni yollar açma potansiyeli taşıyacaktır.

\section{Kaynakça}

ADORNO, T. W. (2005). Aşkınsallık Kavramı Üzerine. Cogito. İstanbul: Yapı Kredi.

BALD0, J. (1985). Theatricality, Generality, Drama: Variations on the Theme of Context in Hamlet. A Quarterly for Literature and the Arts. Spring.

BLO0M, G. (2013). Ophelia's Intertheatricality, or, How Performance is History. Theatre Journal. Vol.65, n.2, May.

BEIER, V. B. (2014). The Art of Persuasion and Shakespeare's Two Iagos. Studies in Philosophy, Vol.111, No.1.

BROOK, P. (2010). Evoking and Forgetting Shakespeare. İstanbul: Hayalbaz.

CARLSON, M. (2013). Performans: Eleştirel Bir Giriş. Ankara: Dost.

EAGLETON, T. (1998) William Shakespeare. İstanbul: Boğaziçi Üniversitesi Yayınevi.

FRIED, M. (2003) Art and Objecthood. Art in Theory 1900-1990. Oxford: Blackwell Publishing.

GOFFMAN, E. (2014) Günlük Yaşamda Benliğin Sunumu. İstanbul: Metis.

GüÇBİLMEZ, B. (2005) Sophokles'ten Stoppard'a İroni ve Dram Sanatı. Ankara: Deniz.

KARABOĞA, K. (2011) Oyunculuk Sanatında Yöntem ve Paradoks. İstanbul: Habitus.

PONTY, M. (2010) Phenomenology of Perception. New York: Routledge.

PONTY, M. (2006) Göz ve Tin. İstanbul: Metis.

RICOEUR, P. (1978). The Metaphorical Process as Cognition, Imagination and Feeling. Critical Inquiry, Vol.5 No.1.

SAYIN, Z. (2000). Beden Yazısı II. İstanbul: Kaknüs.

TRONSTAD, R. (2002). Could the World Become a Stage? Theatricality and Metaphorical Structures. Substance, Vol.31, No.2.
SHAKESPEARE, W. (2005). Hamlet, Çev. Bülent Bozkurt. İstanbul: Remzi.

SHAKESPEARE, W. (1982). Hamlet, London: Penguin.

SHAKESPEARE, W. (2005). Macbeth, Çev. Bülent Bozkurt, İstanbul: Remzi.

SHAKESPEARE, W. (2000). Merchant of Venice, Wordsworth.

SHAKESPEARE, W. (2007). Othello, Çev. Özdemir Nutku, İstanbul: Remzi. 